\title{
Higher body mass index is an important risk factor in COVID-19 patients: a systematic review and meta-analysis
}

\author{
Vivek Singh Malik ${ }^{1,2} \cdot$ Khaiwal Ravindra $^{1}$ (I) $\cdot$ Savita Verma Attri ${ }^{2} \cdot$ Sanjay Kumar Bhadada ${ }^{3} \cdot$ Meenu Singh $^{2}$
}

Received: 17 May 2020 / Accepted: 14 July 2020 / Published online: 24 July 2020

(C) Springer-Verlag GmbH Germany, part of Springer Nature 2020

\begin{abstract}
Globally, both obesity and underweight are severe health risks for various diseases. The current study systematically examined the emerging evidence to identify an association between body mass index (BMI) and COVID-19 disease outcome. Online literature databases (e.g., Google Scholar, PubMed, MEDLINE, EMBASE, Scopus, Medrixv and BioRixv) were screened following standard search strategy having the appropriate keyword such as "Obesity", "Underweight", "BMI", "Body Mass Index", "2019-nCov", "COVID-19, "novel coronavirus", "coronavirus disease". Studies published till $20^{\text {th }}$ April 2020 were included without language restriction. These studies include case reports, case series, cohort, and any other which reported BMI, overweight/obesity or underweight, and its complication with COVID-19 disease. This study observed COVID-19 infection among BMI $<25 \mathrm{~kg} / \mathrm{m}^{2}$ with prevalence of 0.60 (95\% CI: $0.34-0.86, I^{2}=-76.77$ ) as compared to the 0.34 (95\%CI: $0.23-0.44, I^{2}=53.45 \%$ heterogeneity) having BMI $>25 \mathrm{~kg} /$ $\mathrm{m}^{2}$. The results of the current study show that BMI plays a significant role in COVID-19 severity in all age groups, especially the older individuals. A panel of doctors and nursing staff should review COVID-19 patients with higher BMI with other co-morbidities (diabetes and hypertension), and they should be given increased vigilance, priority in testing, and treatment to control the associated co-morbidities. Further, the COVID-19 patients whose illness entered $7-$ 10 days, age $>50$ years, and elevated CRP levels should be given additional medical considerations. Our finding showed that the population and patients with high BMI have moderate to high risk of medical complications with COVID-19, and hence, their health status should be monitored more frequently including monitoring of blood pressure and blood glucose.
\end{abstract}

Keywords Age $\cdot$ Body mass index $\cdot$ BMI $\cdot$ COVID-19 $\cdot$ Obesity

\section{Highlights}

-The study examines the BMI as a risk factor for COVID-19 infection and severity.

-COVID-19 patients with higher BMI need to be monitored regularly for vital parameters.

- COVID-19 patients with higher BMI needs additional vigilance for associated co-morbidities.

-Blood pressure, blood glucose, and hsCRP levels of COVID-19 patients with higher BMI should be periodically monitored.

Responsible Editor: Philippe Garrigues

Khaiwal Ravindra

khaiwal@yahoo.com; khaiwal.ravindra@pgimer.edu.in

1 Department of Community Medicine and School of Public Health, Post Graduate Institute of Medical Education and Research (PGIMER), Chandigarh 160012, India
2 Department of Pediatrics, Post Graduate Institute of Medical Education and Research (PGIMER), Chandigarh 160012, India

3 Department of Endocrinology, Post Graduate Institute of Medical Education and Research (PGIMER), Chandigarh 160012, India 


\section{Introduction}

Being overweight, obese, and underweight may have a major risk factor for multiple disorders in the later stage of life. Earlier studies have shown a relationship between BMI and mortality among diabetic patients (Chang et al. 2016), mental behavioral, neurological (Bhaskaran et al. 2018), and Parkinson's disease (Chen et al. 2014).

Influence of infection on obesity A U-shaped (non-linear relationship) elevated infection rate was seen among overweight/obese and underweight old age persons (Dobner and Kaser 2018), increased CVD risk with greater malignancy rates (Gluvic et al. 2016; Tune et al. 2017; Vucenik and Stains 2012), and obesity with impaired immune responses was seen (Carbone et al. 2016). Overweight/obesity was reported as a risk factor for Clostridium difficile colitis, pneumonia, bacteremia infections (Falagas and Kompoti 2006; Huttunen et al. 2013), and increased surgical site infection (Crabtree et al. 2004; Lillenfeld et al. 1988; Olsen et al. 2003; Thelwall et al. 2015; Tjeertes et al. 2015; Vilar-Compte et al. 2000; Zahr et al. 2011). Similarly, waist circumference was reported as a better predictor of septicemia than BMI (Wang et al. 2013). In a study, adipose tissue serves as a source for human influenza A virus, Trypanosoma gondi, HIV, adenovirus Ad-36, cytomegalovirus, and mycobacterium tuberculosis (Kassir 2020). The elderly population is reported to be more susceptible to infections (Dorner et al. 2010a). Higher mortality risks of influenza were reported among the underweight and obese old population (L. Yang et al. 2013).

Obesity and coronavirus infection In many countries, the obese population is more vulnerable to most of the noncommunicable diseases. Further, the COVID-19 pandemic has put this population at higher risk (Dayal 2020). The measures introduced in some countries, e.g., restriction on leaving home for several weeks even for daily walk, will have an impact on mobility, and these infection control measures resulted in physical inactivity, and even short periods of restriction can increase the risk of metabolic disease in future. Overweight and obesity among severe COVID-19 patients were reported as an independent risk factor (Jose and Manuel 2020). Increased adiposity undermines the pulmonary function contributing the viral pathogenesis as a secondary cause of infection (Dorner et al. 2010) has been reported in obese among older individuals ( $>60$ years of age) (Andersen et al. 2016). Following the 2009 influenza A virus $\mathrm{H}_{1} \mathrm{~N}_{1}$ pandemic (Sun et al. 2016) and adult respiratory distress syndrome (ARDS) (Ni et al. 2017), obesity was reported as a risk factor. Decreased mortality due to ventilator-induced lung injury resulting in chronic pro- inflammatory status in obese patients has been reported (Repine and Fernandez-Bustamante 2013). Infection of influenza A showed that overweight/obesity risk elevates with virus shedding (42\% longer) duration among symptomatic patients with obesity (Milner et al. 2015). In $\mathrm{H}_{1} \mathrm{~N}_{1}$ disease, obesity was reported as a risk factor with increased hospitalization and death rates (Maier et al. 2018). Obesity has been shown to increase vulnerability to infections, serving as a risk factor among COVID-19 patient's mortality rate (Misumi et al. 2019). Potential confounders for obesity and infection risk: smoking (Baik et al. 2000; Nuorti et al. 2000), well-being (Lasselin et al. 2016), physical activity (Krüger et al. 2016), weight loss (Dobner and Kaser 2018), co-morbidities (Pearson-Stuttard et al. 2016), and nutrition (Urwin et al. 2014) are reported independent of age and sex.

\section{Methods}

Search strategy PRISMA guideline was used for this metaanalysis (Moher et al. 2009). Boolean operators: (BMI) AND (COVID-19), (Obesity) AND (COVID-19), ((Underweight) AND (COVID-19)) OR (CASRS-Cov-2), (BMI) OR (Body Mass Index) AND (COVID-19) were used for PubMed database and for Google Scholar, MEDLINE, EMBASE, Scopus, Medrixv and BioRixv using appropriate keywords (e.g., "Obesity", "BMI", "Body Mass Index", "2019-nCov", "COVID-19, "novel coronavirus", "coronavirus disease"). The study included published literature without language restriction until $20^{\text {th }}$ April 2020.

Selection criteria (inclusion/exclusion) Studies with the following conditions had included for the meta-analysis: (1) case report, case series, and cohort studies design; (2) BMI assessment $>25 \mathrm{~kg} / \mathrm{m}^{2}$ and $<25 \mathrm{~kg} / \mathrm{m}^{2}$ reported; (3) indicating the risk ratio and/or odds ratio for the obesity risk; (4) studies reporting cross-sectional were excluded; (5) age and gender were not kept as a bar for inclusion; (6) for meta-analysis, we included BMI with reported COVID-19 infections (clinical, laboratory, or both confirmed); and (7) definition of severe COVID-19 was taken (Xu et al. 2020).

Data extraction Details of authors, total sample size, and numbers reported for obesity and other conditions, e.g., comorbidity (obesity) and clinical condition (critical/severe), were extracted and recorded independently. Data extraction was accomplished by two reviewers (Dr. Khaiwal Ravindra and Dr. Neha Chanana). Any disagreement was resolved by joint discussion. To minimize the risk of duplication, data were carefully handled. Continuous variable (BMI) was expressed as mean $\pm \mathrm{SD} /$ median and IQR (interquartile range). The systematic review include case reports, case series, and observational and any other study types of study design which reported 
obesity and or underweight or its complication of COVID-19 infection. Studies for meta-analysis were pooled only if the outcome measured in the same way by all studies.

Quality assessment The Newcastle-Ottawa scale for cohort studies was used for quality evaluation of the selected studies (Wells 2014). This scale was applied because most of the studies in this study fall under cohort studies (retrospective), analyzing the other studies by covering broad spectra of study design. However, another study used the modified NewcastleOttawa scale for cohort and case-control study design (Codipilly et al. 2018).

Statistical analysis and data synthesis After extracting the results of the studies, the effects of BMI on COVID-19 patients were pooled and were examined using the random effects method. For continuous outcome, standard error (SE) with $95 \%$ CI was calculated. The heterogeneity ( $I^{2}$ statistic) was assessed between studies. Higgins and colleagues suggested $I^{2}$ values $25 \%$ (low), 50\% (moderate), and $75 \%$ (high), indicating the existence of heterogeneity (Ioannidis et al. 2007; Higgins 2003; Higgins and Thompson 2002). Data analysis was undertaken using Microsoft Excel (Neyeloff et al. 2012).

\section{Results}

Literature search Literature searching and screening was done according to PRISMA chart, as shown in Fig. 1. Initially, 3405 published research articles were identified through a database search. After the removal of 3368

Fig. 1 PRISMA chart

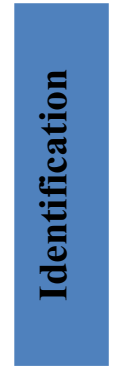

Records identified through database searching (PubMed, MEDLINE, Google scholar) $(n=2587)$
Additional records identified through others sources (BioRixv, Medrixv, and reference) $(n=818)$
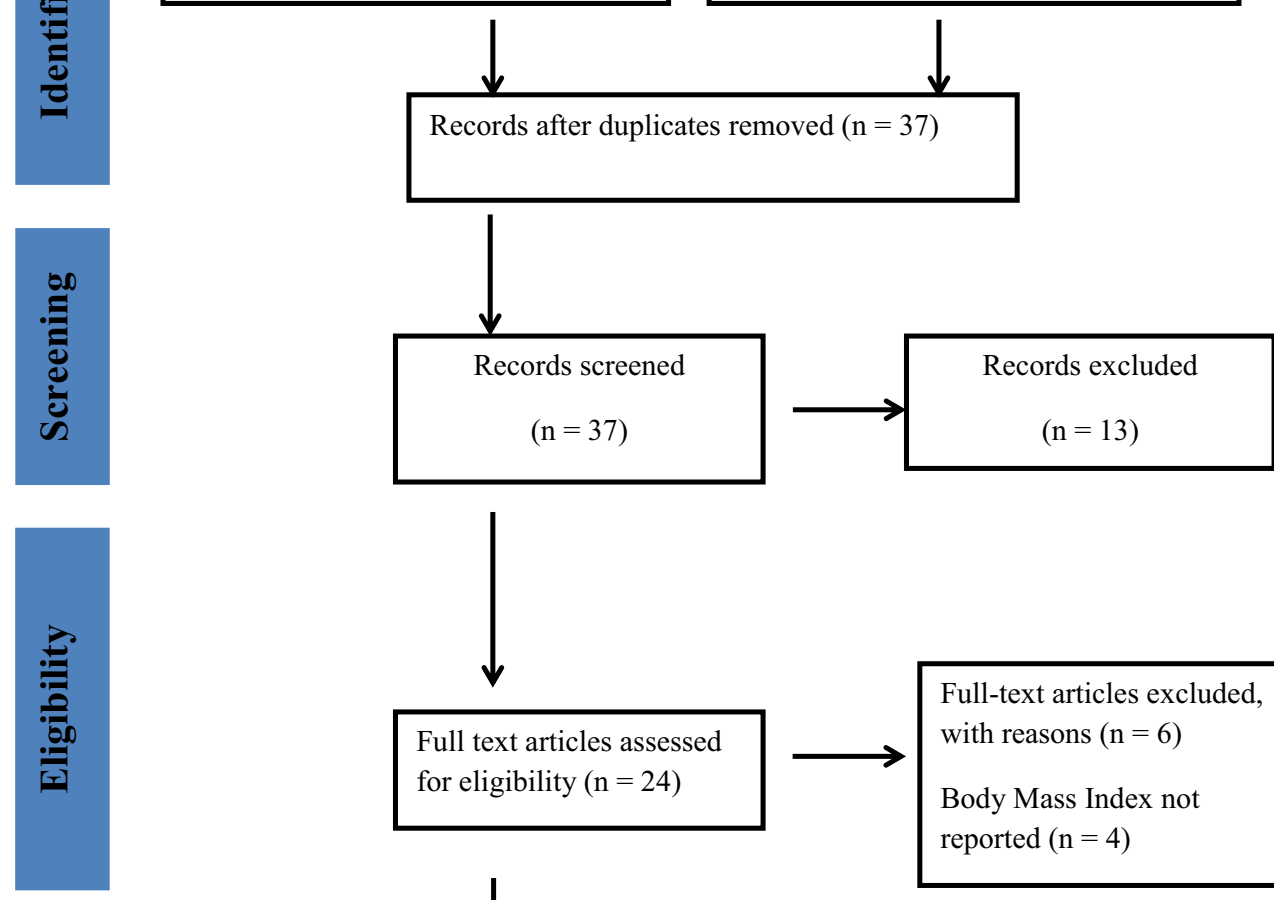

Full text articles assessed for eligibility $(n=24)$

Full-text articles excluded, with reasons $(n=6)$

Body Mass Index not reported $(n=4)$
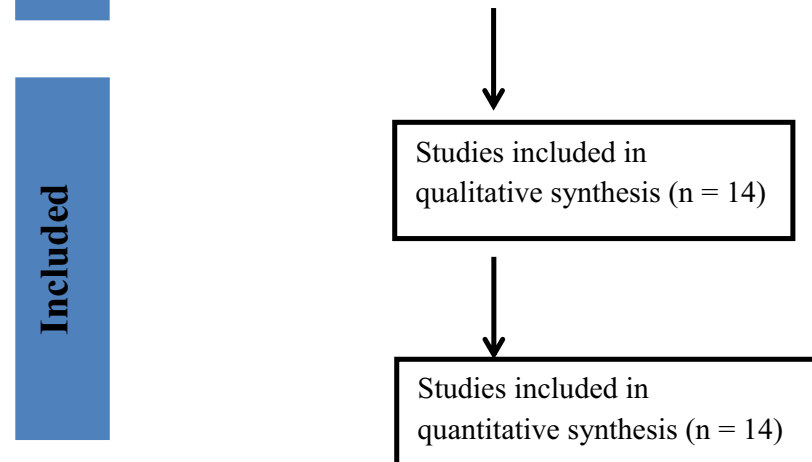
publications due to duplicates and not relevant to study criteria, only 37 research papers were taken for the fulltext paper. Finally, 14 articles that met the inclusion criteria were included in the quantitative synthesis of the current systematic review.

Study characteristics The main characteristics are summarized in Table 1. All published research papers fall under observational (cohort) study design. Most of the studies are from China, the USA, and France. The study included articles published/available online till $20^{\text {th }}$ April 2020. About the obesity criteria, BMI $>25 \mathrm{~kg} / \mathrm{m}^{2}$ was considered as also described in selected studies.

Quality assessment The Newcastle-Ottawa Scale (for cohort studies) was used for the qualitative evaluation of the included studies (Wells 2014). The risk of bias was assessed based on three domains, i.e., selection, comparability, and outcome, as highlighted in Table 2.

Publication bias This study included published studies, as well as unpublished literature on MedRxiv and Bioxiv, as long as it

Table 1 Patient/study characteristics

\begin{tabular}{|c|c|c|c|c|c|c|}
\hline Author (Ref. No.) & Country & Study type & Numbers or $\%$ & $\begin{array}{l}\text { Clinical condition } \\
\text { (COVID-19) }\end{array}$ & $\begin{array}{l}\mathrm{BMI}\left(\mathrm{kg} / \mathrm{m}^{2}\right)(\text { mean } \\
\pm \mathrm{SD} / \text { median }(\mathrm{IQR})\end{array}$ & Outcome \\
\hline $\begin{array}{l}\text { Jose and Manuel } \\
\text { (2020) }\end{array}$ & $\begin{array}{l}\text { China, } \\
\text { Wuhan }\end{array}$ & $\begin{array}{l}\text { Editorial/ } \\
\text { Retrospective }\end{array}$ & $\begin{array}{l}N=112(\mathrm{~T}) \\
N=15 \\
N=18\end{array}$ & $\begin{array}{l}\text { ICU } \\
\text { General }\end{array}$ & $\begin{array}{l}25.5(23.0-27.5) \\
22.0(20.0-24.0)\end{array}$ & $\begin{array}{c}\text { BMI } \uparrow \text { among ICU and } \\
\text { non-survivor group }\end{array}$ \\
\hline Wu et al. (2020) & China & Retrospective & $\begin{array}{l}N=280(\mathrm{~T}) \\
N=83 \\
N=197\end{array}$ & $\begin{array}{l}\text { Severe } \\
\text { Mild }\end{array}$ & $\begin{array}{l}25.8 \pm 1.8 \\
23.6 \pm 3.2\end{array}$ & $\begin{array}{l}\text { BMI } \uparrow \text { among severe COVID-19 } \\
\text { group }\end{array}$ \\
\hline Liu et al. (2020) & China & Retrospective & $N=30(\mathrm{~T})$ & $\begin{array}{l}\text { Critical } \\
\text { General }\end{array}$ & $\begin{array}{l}27.0 \pm 2.5 \\
22.0 \pm 1.3\end{array}$ & $\begin{array}{l}\text { BMI } \uparrow \text { among critical COVID-19 } \\
\text { group }\end{array}$ \\
\hline Garg et al. (2020) & USA & COVID-NET & $\begin{array}{l}N=151(\mathrm{~T}) \\
N=73\end{array}$ & & $\geq 30 \mathrm{~kg} / \mathrm{m}^{2}$ & $\begin{array}{l}\text { BMI } \uparrow \text { Hospitalization rate } \uparrow \text { with } \\
\text { age and older adults. }\end{array}$ \\
\hline $\begin{array}{l}\text { Simonnet et al. } \\
(2020)\end{array}$ & France & Retrospective & $\begin{array}{l}N=124 \\
N=107\end{array}$ & & $>30 \mathrm{~kg} / \mathrm{m}^{2}$ & $\begin{array}{l}\text { BMI } \uparrow \text { Invasive Mechanical } \\
\text { Ventilation (IMV) } \\
\text { requirement } \uparrow\end{array}$ \\
\hline $\begin{array}{l}\text { Lighter et al. } \\
\text { (2020b) }\end{array}$ & USA & Retrospective & $\begin{array}{l}N=1370(\mathrm{~T}) \\
N=202\end{array}$ & & $>30 \mathrm{~kg} / \mathrm{m}^{2}$ & $\begin{array}{l}\text { Significant difference in } \\
\text { admission and ICU care only } \\
\text { in patients }<60 \text { years of age } \\
\text { with varying BMIs. }\end{array}$ \\
\hline Guo et al. (2020) & China & Retrospective & $\begin{array}{l}N=159 \\
N=02\end{array}$ & & $>25 \mathrm{~kg} / \mathrm{m}^{2}$ & $\begin{array}{l}\text { Most death among elder adults } \\
\text { and } 1.65 \text {-fold higher in male } \\
\text { than female. }\end{array}$ \\
\hline Liao et al. (2020) & China & Retrospective & $\begin{array}{l}N=46(\mathrm{~T}) \\
N=17 \\
N=24\end{array}$ & & $\begin{array}{l}\mathrm{BMI} \geq 25 \\
\mathrm{BMI}<25\end{array}$ & $\begin{array}{l}\text { Adolescent and young adult had } \\
\text { long COVID-19 incubation } \\
\text { period }\end{array}$ \\
\hline Qi et al. (2020) & $\begin{array}{l}\text { China, } \\
\text { Chongqing }\end{array}$ & Retrospective & $\begin{array}{l}N=267 \\
N=30(11.2 \%)\end{array}$ & & $\mathrm{BMI}>25$ & $\begin{array}{l}\text { Severe were older ( } 71.5 \text { years) } \\
\text { and overweight/obese } 14 \\
(28 \%)\end{array}$ \\
\hline Hu et al. (2020) & $\begin{array}{l}\text { China, } \\
\text { Wuhan }\end{array}$ & Retrospective & $\begin{array}{l}N=323(\mathrm{~T}) \\
N=141 \\
N=256\end{array}$ & $\begin{array}{l}\text { Severe } \\
\text { Non-severe }\end{array}$ & $\begin{array}{l}\geq 25 \\
<25\end{array}$ & \\
\hline Yang et al. (2020) & China & Retrospective & $\begin{array}{l}N=55(\mathrm{~T}) \\
N=21 \\
N=34\end{array}$ & $\begin{array}{l}\text { Without pneumonia } \\
\text { With pneumonia }\end{array}$ & $\begin{array}{l}24.85(22.86-26.79) \\
26.12(22.86-27.68) \\
24.54(22.89-26 \cdot 27)\end{array}$ & \\
\hline Cai et al. (2020) & China & Retrospective & $\begin{array}{l}N=298(\mathrm{~T}) \\
N=240 \\
N=58\end{array}$ & $\begin{array}{l}\text { Non-severe } \\
\text { Severe }\end{array}$ & $\begin{array}{l}23.2(21.1-25.6) \\
22.9(20.6-25.2) \\
24.5(22.0-27.8)\end{array}$ & BMI $\uparrow$ among elder \\
\hline Xu et al. (2020) & China & Meta-analysis & $N=79$ & & & $\begin{array}{l}\text { WMD } 3.38(0.07-6.69) \\
\qquad I^{2}=67.20 \%\end{array}$ \\
\hline Petrilli et al. (2020) & USA & Cross-Sectional & $\begin{array}{l}N=4103(\mathrm{~T}) \\
N=2104 \\
N=1999\end{array}$ & $\begin{array}{l}\text { Not hospitalized } \\
\text { Hospitalized }\end{array}$ & $\begin{array}{l}\text { BMI } 30-40 \\
\text { BMI } 30-40\end{array}$ & $\begin{array}{l}\text { High BMI had higher } \\
\text { hospitalization rate OR } 6.2 \\
(4.21-9.25)\end{array}$ \\
\hline
\end{tabular}


Table 2 Quality assessment: cohort study quality according to Newcastle-Ottawa Scale

\begin{tabular}{|c|c|c|c|c|c|c|c|c|c|}
\hline \multirow[t]{2}{*}{ S.No. } & \multicolumn{4}{|c|}{ Selection $* * * * * *$} & \multirow{2}{*}{$\begin{array}{l}\text { Comparability** } \\
5\end{array}$} & \multicolumn{3}{|c|}{ Outcome $* * * * *$} & \multirow[t]{2}{*}{ Total quality score } \\
\hline & 1 & 2 & 3 & 4 & & 6 & 7 & 8 & \\
\hline Jose and Manuel (2020) & $*$ & 0 & * & 0 & 0 & $* *$ & 0 & 0 & 3 \\
\hline Wu et al. (2020) & $*$ & 0 & * & 0 & $*$ & $* *$ & 0 & 0 & 4 \\
\hline Garg et al. (2020) & $*$ & 0 & * & 0 & 0 & $* *$ & 0 & 0 & 3 \\
\hline Simonnet et al. (2020) & $*$ & 0 & * & $*$ & $*$ & $* *$ & 0 & 0 & 5 \\
\hline Lighter et al. (2020b) & $*$ & 0 & * & $*$ & 0 & $* *$ & 0 & 0 & 4 \\
\hline Liao et al. (2020) & $*$ & 0 & * & $*$ & 0 & 0 & 0 & 0 & 3 \\
\hline Qi et al. (2020) & $*$ & 0 & * & 0 & 0 & $* *$ & $*$ & 0 & 4 \\
\hline Hu et al. (2020) & $*$ & 0 & * & 0 & $*$ & $* *$ & 0 & 0 & 4 \\
\hline Yang et al. (2020) & $*$ & 0 & * & 0 & $*$ & $* *$ & $*$ & 0 & 5 \\
\hline Cai et al. (2020) & $*$ & 0 & $*$ & 0 & * & $* *$ & 0 & 0 & 4 \\
\hline
\end{tabular}

Note: Selection: (1) representativeness of the exposed cohort, (2) selection of the non-exposed cohort, (3) ascertain exposure, (4) demonstration that outcome of interest was not resent at stat of study; comparability; (5) comparability of cohorts on the basis of the design or analysis controlled for confounders; outcome: (6) assessment of outcome, (7) was followed up long enough for outcomes to occur, (8) adequacy of follow-up of cohorts. meets study inclusion criteria. Possible publication bias was not calculated due to the limited power among studies, and the outcome was $<10$ for funnel plot (Lau et al. 2006).

Meta-analysis The outcomes of the meta-analysis (Table 3) and forest plot (Figs. 2 and 3) are shown. A random-effects model $\left(I^{2}=53.45 \%\right)$ was used on 9 articles for those reported $\geq 25 \mathrm{BMI} \mathrm{kg} / \mathrm{m}^{2}$ for COVID-19 infection involving 689 patients to analyze the risk factors of $\geq 25 \mathrm{BMI} \mathrm{kg} / \mathrm{m}^{2}$ [prevalence, 95\%CI: $0.34(0.23-0.44)]$ for patients with COVID-19 than those of having $<25 \mathrm{BMI} \mathrm{kg} / \mathrm{m}^{2}$ [prevalence, $95 \% \mathrm{CI}$ : $0.60(0.34-0.86)]$ with random-effect model $\left(I^{2}=0 \%\right)$. BMI < $25 \mathrm{~kg} / \mathrm{m}^{2}$ random effect models $I^{2}$ were negative, which indicates no observed heterogeneity for this group (Higgins 2003; Melsen et al. 2014).

\section{Discussion}

This study summarized available studies from retrospective about BMI and COVID-19 infection. We observed prevalence rate from 0.11 (95\%CI: $0.07-0.15)$ to 0.86 (95\%CI: $0.69-$ 1.02) among COVID-19 patients having BMI $>25 \mathrm{~kg} / \mathrm{m}^{2}$. Similarly, those having BMI $<25 \mathrm{~kg} / \mathrm{m}^{2}$ show prevalence rate from 0.16 (95\%CI: $0.08-0.23$ ) to 0.80 (95\%CI: $0.70-0.90$ ) studies included in the meta-analysis. This study observed heterogeneity of $53.45 \%$ among COVID-19 patients with BMI $>25 \mathrm{~kg} / \mathrm{m}^{2}$. This might be due to the various variables, age, and gender. The previous study suggests $30 \%$ prevalence of obesity in MERS-CoV infection (Badawi and Ryoo 2016) with pooled prevalence in obesity of $16 \pm 2 \%$ (95\%CI: 12 $19 \%$ ). Similarly, other studies observed the relationship between weight gain with pneumonia (Baik et al. 2000), infection rate among weight-reduced patients (Anderin et al. 2015), and thromboembolic risk in obese (Kassir 2020) population. COVID-19 patient with high BMI has moderate to high risk of medical complication with infection; hence, their periodic health status of co-morbidities, e.g., hypertension and diabetes, should be evaluated. Also, there is geographical variation in fatality case rates in South Korea (0.8), China (2.3), and Italy (7.2) that has been reported (Onder et al. 2020) with risk factors of smoking, pollution, and aging. In US patients, $<60$ years and with BMI 30-40 (OR (95\%CI) 1.8: 1.2-2.7) were more likely to be admitted to acute and critical care to individuals with a BMI $<30$ (Lighter et al. 2020a) that has been reported for the first time. In a study, gender (male), age, and heart disease were the main risk factors of COVID-19-related death (Guo et al. 2020). Adolescents and young adults might play a key role in the worldwide spread of COVID-19 disease because they study overseas and frequently travel (Liao et al.
Table 3 The meta-analysis of body mass index for COVID-19 patients

\begin{tabular}{llllll}
\hline Risk factor & Variable & Number of studies & Size $(n)$ & Prevalence $(95 \% \mathrm{CI})$ & $I^{2}$ \\
\hline $\begin{array}{l}\text { Body mass index } \\
<25 \mathrm{~kg} / \mathrm{m}^{2}\end{array}$ & Continuous & 6 & 769 & $0.60(0.34-0.86)$ & $0 \%(-76.77)$ \\
$>25 \mathrm{~kg} / \mathrm{m}^{2}$ & Continuous & 9 & 689 & $0.34(0.23-0.44)$ & $53.45 \%$ \\
\hline
\end{tabular}




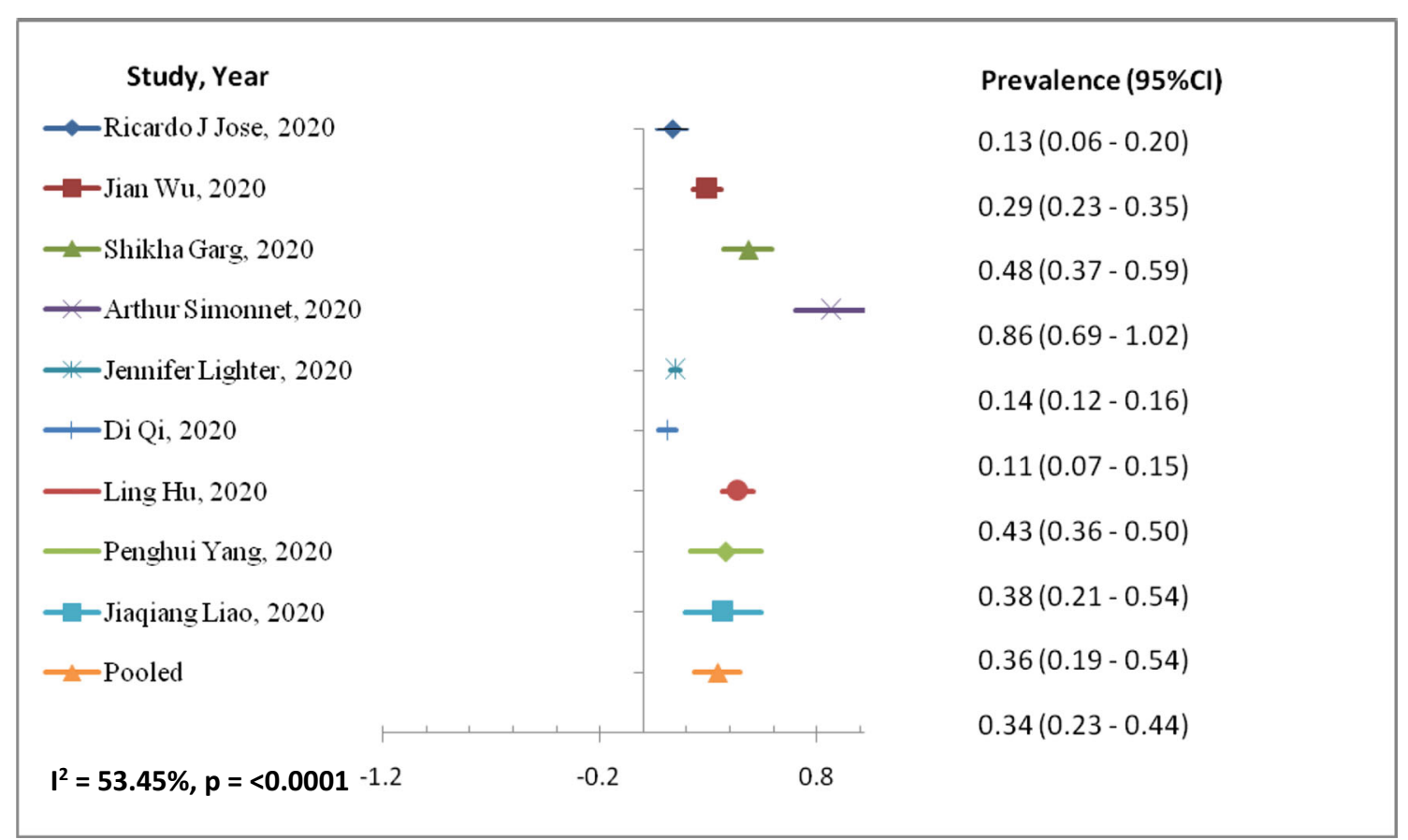

Fig. 2 Forest plot of risk factor BMI $>25 \mathrm{~kg} / \mathrm{m}^{2}$ with COVID-19 patients

2020). Meta-analysis showed that elderly male patients with high BMI have greater chances of being into critically ill patient category (53). This study observed prevalence rate 0.60 (95\%CI: 0.34-0.86) of COVID-19 infection among $<25 \mathrm{~kg} /$ $\mathrm{m}^{2} \mathrm{BMI}$ population with no heterogeneity as compared to the $>25 \mathrm{~kg} / \mathrm{m}^{2}$ BMI, 0.34 , 95\% CI: 0.23-0.44 with heterogeneity of $53.4 \%$ among study population.

Limitations Population, continuous variable, clinical condition, and statistical methods have the potency to differ and may cause heterogeneity among studies included for the meta-analysis. Further, the study reviewed only the risk of BMI ( $>25 \mathrm{~kg} / \mathrm{m}^{2}$ and $<25 \mathrm{~kg} / \mathrm{m}^{2}$ ) of COVID-19 subjects and their severity.

\section{Conclusion}

The BMI plays a significant role in COVID-19 infection and severity at all ages, especially elderly population. COVID-19 patients with higher BMI should be reviewed by a panel for the risk factors. Further, there should be a procedure for

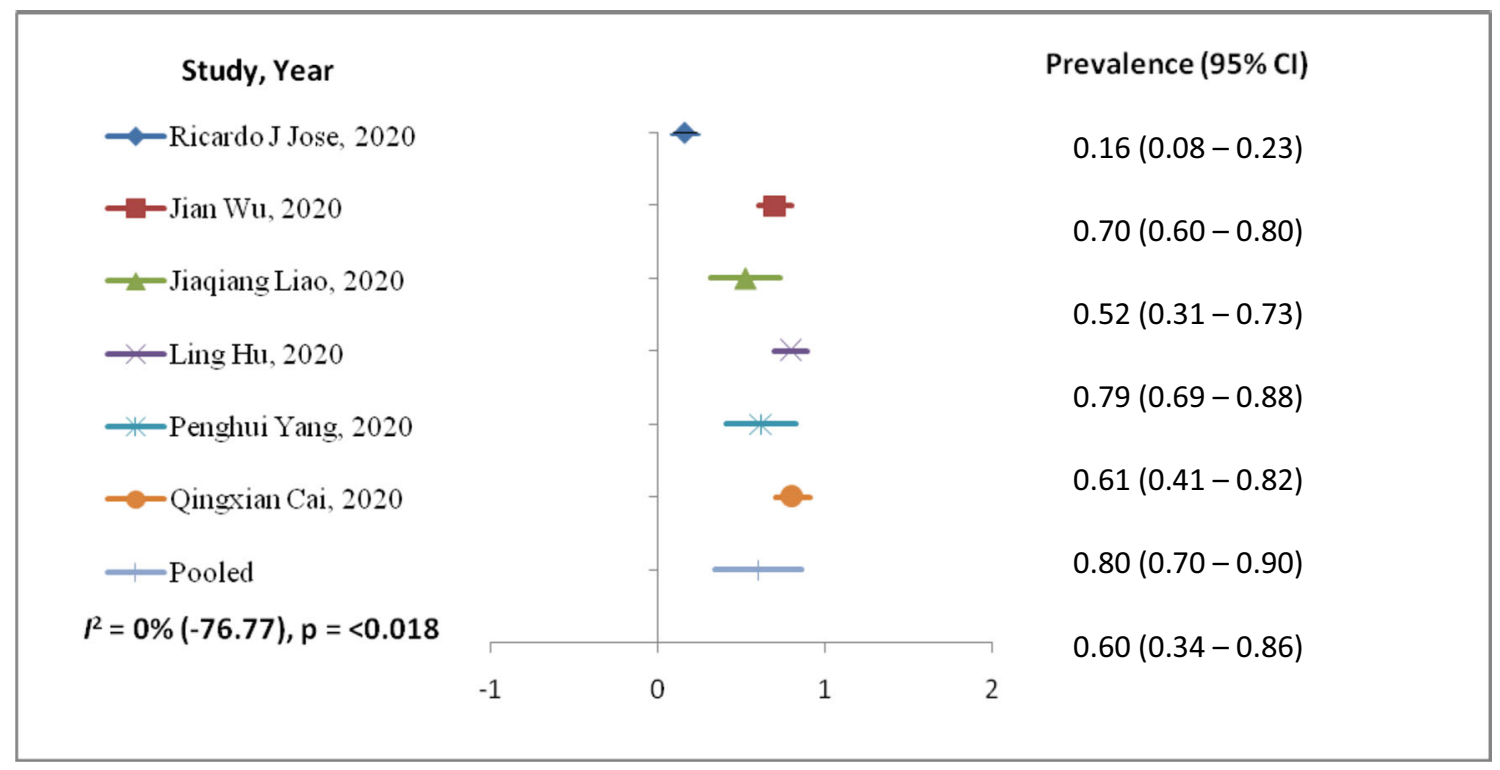

Fig. 3 Forest plot of risk factor BMI $<25 \mathrm{~kg} / \mathrm{m}^{2}$ with COVID-19 patients 
increased vigilance, testing priority, and therapy for patients with obesity and COVID-19 disease, whose illness has entered 7-10 days, having age $>50$ years, and elevated CRP levels. The severity of COVID-19 found has a significant burden on intensive care resources in hospitals worldwide and specifically in lower-and-middle income countries due to lack of health finance and resources. Hence, the patients having higher BMI with other comorbidities should be given special attention to reduce morbidity and mortality associated with COVID-19 infection.

\section{Compliance with ethical standards}

Conflict of Interest The authors declare that they have no conflict of interest.

\section{References}

Anderin C, Gustafsson UO, Heijbel N, Thorell A (2015) Weight loss before bariatric surgery and postoperative complications: data from the Scandinavian Obesity Registry (SOReg). Ann Surg 261(5):909913. https://doi.org/10.1097/SLA.0000000000000839

Andersen CJ, Murphy KE, Fernandez ML (2016) Impact of obesity and metabolic syndrome on immunity. Adv Nutr 7(1):66-75. https://doi. org/10.3945/an.115.010207

Badawi A, Ryoo SG (2016) Prevalence of comorbidities in the Middle East respiratory syndrome coronavirus (MERS-CoV): a systematic review and meta-analysis. Int J Infect Dis 49:129-133

Baik I, Curhan GC, Rimm EB, Bendich A, Willett WC, Fawzi WW (2000) A prospective study of age and lifestyle factors in relation to community-acquired pneumonia in US men and women. Arch Intern Med 160(20):3082-3088. https://doi.org/10.1001/archinte. 160.20 .3082

Bhaskaran K, dos-Santos-Silva I, Leon DA, Douglas IJ, Smeeth L (2018) Association of BMI with overall and cause-specific mortality: a population-based cohort study of 3.6 million adults in the UK. Lancet Diabetes Endocrinol 6(12):944-953. https://doi.org/10. 1016/S2213-8587(18)30288-2

Cai Q, Huang D, Ou P, Yu H, Zhu Z, Xia Z, Su Y, Ma Z, Zhang Y, Li Z, He Q, Liu L, Fu Y, Chen J (2020) COVID-19 in a designated infectious diseases hospital outside Hubei Province, China. Allergy, all.14309. https://doi.org/10.1111/all.14309

Carbone F, La Rocca C, De Candia P, Procaccini C, Colamatteo A, Micillo T, De Rosa V, Matarese G (2016) Metabolic control of immune tolerance in health and autoimmunity. Semin Immunol 28(5):491-504. https://doi.org/10.1016/j.smim.2016.09.006

Chang H-W, Li Y-H, Hsieh C-H, Liu P-Y, Lin G-M (2016) Association of body mass index with all-cause mortality in patients with diabetes: a systemic review and meta-analysis. Cardiovasc Diagn Ther 6(2):109-119. https://doi.org/10.21037/cdt.2015.12.06

Chen J, Guan Z, Wang L, Song G, Ma B, Wang Y (2014) Meta-analysis: overweight, obesity, and Parkinson's disease. Int J Endocrinol 2014: 1-7. https://doi.org/10.1155/2014/203930

Codipilly DC, Chandar AK, Singh S, Wani S, Shaheen NJ, Inadomi JM, Chak A, Iyer PG (2018) The effect of endoscopic surveillance in patients with Barrett's esophagus: a systematic review and metaanalysis. Gastroenterology 154(8):2068-2086

Crabtree TD, Codd JE, Fraser VJ, Bailey MS, Olsen MA, Damiano RJ (2004) Multivariate analysis of risk factors for deep and superficial sternal infection after coronary artery bypass grafting at a tertiary care medical center. Semin Thorac Cardiovasc Surg 16(1):53-61. https://doi.org/10.1053/j.semtcvs.2004.01.009

Dayal D (2020) COVID-19: Considerations for children and adolescents with diabetes [Preprint]. Med Pharmacol. https://doi.org/10.20944/ preprints202004.0225.v1

Dobner J, Kaser S (2018) Body mass index and the risk of infectionfrom underweight to obesity. Clin Microbiol Infect 24(1):24-28. https://doi.org/10.1016/j.cmi.2017.02.013

Dorner TE, Schwarz F, Kranz A, Freidl W, Rieder A, Gisinger C (2010) Body mass index and the risk of infections in institutionalised geriatric patients. Br J Nutr 103(12):1830-1835. https://doi.org/10. 1017/S0007114510000152

Falagas ME, Kompoti M (2006) Obesity and infection. Lancet Infect Dis 6(7):438-446. https://doi.org/10.1016/S1473-3099(06)70523-0

Garg S, Kim L, Whitaker M, O'Halloran A, Cummings C, Holstein R, Prill M, Chai SJ, Kirley PD, Alden NB, Kawasaki B, YouseyHindes K, Niccolai L, Anderson EJ, Openo KP, Weigel A, Monroe ML, Ryan P, Henderson J et al (2020) Hospitalization rates and characteristics of patients hospitalized with laboratoryconfirmed coronavirus disease 2019-COVID-NET, 14 States, March 1-30, 2020. MMWR. Morbidity and Mortality Weekly Report 69(15):458-464. https://doi.org/10.15585/mmwr. $\mathrm{mm} 6915 \mathrm{e} 3$

Gluvic Z, Zaric B, Resanovic I, Obradovic M, Mitrovic A, Radak D, Isenovic E (2016) Link between metabolic syndrome and insulin resistance. Curr Vasc Pharmacol 15(1):30-39. https://doi.org/10. 2174/1570161114666161007164510

Guo A-X, Cui J-J, OuYang Q-Y, He L, Guo C-X, Yin J-Y (2020) The clinical characteristics and mortal causes analysis of COVID-19 death patients [Preprint]. Infect Dis (except HIV/AIDS). https:// doi.org/10.1101/2020.04.12.20062380

Higgins JPT (2003) Measuring inconsistency in meta-analyses. BMJ 327(7414):557-560. https://doi.org/10.1136/bmj.327.7414.557

Higgins JPT, Thompson SG (2002) Quantifying heterogeneity in a metaanalysis. Stat Med 21(11):1539-1558. https://doi.org/10.1002/sim. 1186

Hu L, Chen S, Fu Y, Gao Z, Long H, Ren H, Zuo Y, Li H, Wang J, Xv Q, Yu W, Liu J, Shao C, Hao J, Wang C, Ma Y, Wang Z, Yanagihara R, Wang J, Deng Y (2020) Risk factors associated with clinical outcomes in 323 COVID-19 patients in Wuhan, China [Preprint]. Infect Dis (except HIV/AIDS). https://doi.org/10.1101/2020.03.25. 20037721

Huttunen R, Karppelin M, Syrjänen J (2013) Obesity and nosocomial infections. J Hosp Infect 85(1):8-16. https://doi.org/10.1016/j.jhin. 2013.06.012

Ioannidis JPA, Patsopoulos NA, Evangelou E (2007) Uncertainty in heterogeneity estimates in meta-analyses. BMJ 335(7626):914-916. https://doi.org/10.1136/bmj.39343.408449.80

Jose RJ, Manuel A (2020) Does COVID-19 disprove the obesity paradox in ARDS? Obesity. 28:1007. https://doi.org/10.1002/oby.22835

Kassir R (2020) Risk of COVID-19 for patients with obesity. Obes Rev 21:e13034. https://doi.org/10.1111/obr.13034

Krüger K, Mooren F-C, Pilat C (2016) The immunomodulatory effects of physical activity. Curr Pharm Des 22(24):3730-3748. https://doi. org/10.2174/1381612822666160322145107

Lasselin J, Alvarez-Salas E, Grigoleit J-S (2016) Well-being and immune response: a multi-system perspective. Curr Opin Pharmacol 29:34 41. https://doi.org/10.1016/j.coph.2016.05.003

Lau J, Ioannidis JPA, Terrin N, Schmid CH, Olkin I (2006) The case of the misleading funnel plot. BMJ 333(7568):597-600. https://doi. org/10.1136/bmj.333.7568.597

Liao J, Fan S, Chen J, Wu J, Xu S, Guo Y, Li C, Zhang X, Wu C, Mou H, Song C, Li F, Wu G, Zhang J, Guo L, Liu H, Lv J, Xu L, Lang C (2020) Epidemiological and clinical characteristics of COVID-19 in adolescents and young adults [Preprint]. Epidemiology. https://doi. org/10.1101/2020.03.10.20032136 
Lighter J, Phillips M, Hochman S, Sterling S, Johnson D, Francois F, Stachel A (2020a) Obesity in patients younger than 60 years is a risk factor for Covid-19 hospital admission. Clinical Infectious Diseases, ciaa415. https://doi.org/10.1093/cid/ciaa415

Lighter J, Phillips M, Hochman S, Sterling S, Johnson D, Francois F, Stachel A (2020b) Obesity in patients younger than 60 years is a risk factor for Covid-19 hospital admission. Clin Infect Dis, ciaa415. https://doi.org/10.1093/cid/ciaa415

Lillenfeld DE, Vlahov D, Tenney JH, McLaughlin JS (1988) Obesity and diabetes as risk factors for postoperative wound infections after cardiac surgery. Am J Infect Control 16(1):3-6. https://doi.org/10. 1016/0196-6553(88)90003-X

Liu M, He P, Liu HG, Wang XJ, Li FJ, Chen S, Lin J, Chen P, Liu JH, Li $\mathrm{CH}$ (2020) Clinical characteristics of 30 medical workers infected with new coronavirus pneumonia. ZhonghuaJie He He Hu Xi ZaZhi = ZhonghuaJiehe He HuxiZazhi $=$ Chinese Journal of Tuberculosis and Respiratory Diseases, 43(0), E016. https://doi.org/10.3760/cma. j.issn.1001-0939.2020.0016

Maier HE, Lopez R, Sanchez N, Ng S, Gresh L, Ojeda S, BurgerCalderon R, Kuan G, Harris E, Balmaseda A, Gordon A (2018) Obesity increases the duration of influenza A virus shedding in adults. J Infect Dis 218(9):1378-1382. https://doi.org/10.1093/ infdis/jiy 370

Melsen WG, Bootsma MCJ, Rovers MM, Bonten MJM (2014) The effects of clinical and statistical heterogeneity on the predictive values of results from meta-analyses. Clin Microbiol Infect 20(2):123-129. https://doi.org/10.1111/1469-0691.12494

Milner JJ, Rebeles J, Dhungana S, Stewart DA, Sumner SCJ, Meyers MH, Mancuso P, Beck MA (2015) Obesity increases mortality and modulates the lung metabolome during pandemic H1N1 influenza virus infection in mice. J Immunol 194(10):4846-4859. https:// doi.org/10.4049/jimmunol.1402295

Misumi I, Starmer J, Uchimura T, Beck MA, Magnuson T, Whitmire JK (2019) Obesity expands a distinct population of T cells in adipose tissue and increases vulnerability to infection. Cell Rep 27(2):514524.e5. https://doi.org/10.1016/j.celrep.2019.03.030

Moher D, Liberati A, Tetzlaff J, Altman DG, The PRISMA Group (2009) Preferred reporting items for systematic reviews and meta-analyses: the PRISMA statement. PLoS Med 6(7):e1000097. https://doi.org/ 10.1371/journal.pmed.1000097

Neyeloff JL, Fuchs SC, Moreira LB (2012) Meta-analyses and Forest plots using a microsoft excel spreadsheet: step-by-step guide focusing on descriptive data analysis. BMC Res Notes 5(1):52. https:// doi.org/10.1186/1756-0500-5-52

Ni Y-N, Luo J, Yu H, Wang Y-W, Hu Y-H, Liu D, Liang B-M, Liang ZA (2017) Can body mass index predict clinical outcomes for patients with acute lung injury/acute respiratory distress syndrome? A metaanalysis. Crit Care 21(1):36. https://doi.org/10.1186/s13054-0171615-3

Nuorti JP, Butler JC, Farley MM, Harrison LH, McGeer A, Kolczak MS, Breiman RF (2000) Cigarette smoking and invasive pneumococcal disease. N Engl J Med 342(10):681-689. https://doi.org/10.1056/ NEJM200003093421002

Olsen MA, Mayfield J, Lauryssen C, Polish LB, Jones M, Vest J, Fraser VJ (2003) Risk factors for surgical site infection in spinal surgery. J Neurosurg 98(2 Suppl):149-155

Onder G, Rezza G, Brusaferro S (2020) Case-fatality rate and characteristics of patients dying in relation to COVID-19 in Italy. JAMA. https://doi.org/10.1001/jama.2020.4683

Pearson-Stuttard J, Blundell S, Harris T, Cook DG, Critchley J (2016) Diabetes and infection: assessing the association with glycaemic control in population-based studies. Lancet Diabetes Endocrinol 4(2):148-158. https://doi.org/10.1016/S2213-8587(15)00379-4

Petrilli CM, Jones SA, Yang J, Rajagopalan H, O’Donnell LF, Chernyak Y, Tobin K, Cerfolio RJ, Francois F, Horwitz LI (2020) Factors associated with hospitalization and critical illness among 4,103 patients with COVID-19 disease in New York City [Preprint]. Intensive Care Crit Care Med. https://doi.org/10.1101/2020.04.08. 20057794

Qi D, Yan X, Tang X, Peng J, Yu Q, Feng L, Yuan G, Zhang A, Chen Y, Yuan J, Huang X, Zhang X, Hu P, Song Y, Qian C, Sun Q, Wang D, Tong J, Xiang J (2020) Epidemiological and clinical features of 2019-nCoV acute respiratory disease cases in Chongqing municipality, China: a retrospective, descriptive, multiple-center study [Preprint]. Respir Med. https://doi.org/10.1101/2020.03.01. 20029397

Repine JE, Fernandez-Bustamante A (2013) Adipose-lung cell crosstalk in the obesity-ARDS Paradox. J Pulmon Respir Med 3:2. https://doi. org/10.4172/2161-105X.1000144

Simonnet A, Chetboun M, Poissy J, Raverdy V, Noulette J, Duhamel A, Labreuche J, Mathieu D, Pattou F, Jourdain M, The Lille intensive care COVID-19 and obesity study group (2020) High prevalence of obesity in severe acute respiratory syndrome coronavirus-2 (SARSCoV-2) requiring invasive mechanical ventilation. Obesity. 28: 1195-1199. https://doi.org/10.1002/oby.22831

Sun Y, Wang Q, Yang G, Lin C, Zhang Y, Yang P (2016) Weight and prognosis for influenza $\mathrm{A}(\mathrm{H} 1 \mathrm{~N} 1) \mathrm{pdm} 09$ infection during the pandemic period between 2009 and 2011: a systematic review of observational studies with meta-analysis. Infect Dis Ther 48(11-12): 813-822. https://doi.org/10.1080/23744235.2016.1201721

Thelwall S, Harrington P, Sheridan E, Lamagni T (2015) Impact of obesity on the risk of wound infection following surgery: results from a nationwide prospective multicentre cohort study in England. Clin Microbiol Infect 21(11):1008.e1-1008.e8. https://doi.org/10.1016/j. cmi.2015.07.003

Tjeertes EEKM, Hoeks SSE, Beks SSBJC, Valentijn TTM, Hoofwijk AAGM, Stolker RJRJ (2015) Obesity - a risk factor for postoperative complications in general surgery? BMC Anesthesiol 15(1):112. https://doi.org/10.1186/s12871-015-0096-7

Tune JD, Goodwill AG, Sassoon DJ, Mather KJ (2017) Cardiovascular consequences of metabolic syndrome. Transl Res 183:57-70. https://doi.org/10.1016/j.trsl.2017.01.001

Urwin HJ, Miles EA, Noakes PS, Kremmyda L-S, Vlachava M, Diaper ND, Godfrey KM, Calder PC, Vulevic J, Yaqoob P (2014) Effect of salmon consumption during pregnancy on maternal and infant faecal microbiota, secretory IgA and calprotectin. Br J Nutr 111(5):773784. https://doi.org/10.1017/S0007114513003097

Vilar-Compte D, Mohar A, Sandoval S, de la Rosa M, Gordillo P, Volkow P (2000) Surgical site infections at the National Cancer Institute in Mexico: a case-control study. Am J Infect Control 28(1):14-20. https://doi.org/10.1016/S0196-6553(00)90006-3

Vucenik I, Stains JP (2012) Obesity and cancer risk: evidence, mechanisms, and recommendations: Obesity and cancer. Ann N Y Acad Sci 1271(1):37-43. https://doi.org/10.1111/j.1749-6632.2012. 06750.x

Wang HE, Griffin R, Judd S, Shapiro NI, Safford MM (2013) Obesity and risk of sepsis: a population-based cohort study: Obesity and Risk of Sepsis. Obesity 21(12):E762-E769. https://doi.org/10. 1002/oby.20468

Wells G (2014) Newcastle-Ottawa quality assessment scale cohort studies. University of Ottawa

Wu J, Li W, Shi X, Chen Z, Jiang B, Liu J, Wang D, Liu C, Meng Y, Cui L, Yu J, Cao H, Li L (2020) Early antiviral treatment contributes to alleviate the severity and improve the prognosis of patients with novel coronavirus disease (COVID-19). J Intern Med:joim.13063. https://doi.org/10.1111/joim.13063

Xu L, Yaqian M, Chen G (2020) Risk factors for severe corona virus disease 2019 (COVID-19) patients: a systematic review and meta analysis [Preprint]. Infect Dis (except HIV/AIDS). https://doi.org/ 10.1101/2020.03.30.20047415

Yang L, Chan KP, Lee RS, Chan WM, Lai HK, Thach TQ, Chan KH, Lam TH, Peiris JSM, Wong CM (2013) Obesity and influenza 
associated mortality: evidence from an elderly cohort in Hong Kong. Prev Med 56(2):118-123. https://doi.org/10.1016/j.ypmed.2012.11. 017

Yang P, Ding Y, Xu Z, Pu R, Li P, Yan J, Liu J, Meng F, Huang L, Shi L, Jiang T, Qin E, Zhao M, Zhang D, Zhao P, Yu L, Wang Z, Hong Z, Xiao Z, Wang F (2020) Epidemiological and clinical features of COVID-19 patients with and without pneumonia in Beijing, China [Preprint]. Epidemiology. https://doi.org/10.1101/2020.02.28. 20028068
Zahr F, Genovese E, Mathier M, Shullo M, Lockard K, Zomak R, McNamara D, Toyoda Y, Kormos RL, Teuteberg JJ (2011) Obese patients and mechanical circulatory support: weight loss, adverse events, and outcomes. Ann Thorac Surg 92(4):1420-1426. https:// doi.org/10.1016/j.athoracsur.2011.05.085

Publisher's note Springer Nature remains neutral with regard to jurisdictional claims in published maps and institutional affiliations. 